\title{
Cento e uma lamparinas de manteiga: tradução da poesia de Tsering Wangmo Dhompa
}

Luci Collin

Resumo: Este artigo apresenta quatro poemas da escritora tibetana no exílio Tsering Wangmo Dhompa traduzidos do inglês para o português.

Palavras-chave: Tsering Wangmo; exílio; Tibete; bardo; poesia

Abstract: This article presents the poetic translation of four of Tibetan exile writer Tsering Wangmo Dhompa's poems from English into Brazilian-Portuguese.

Keywords: Tsering Wangmo; exile; Tibet; bardo; poetry 


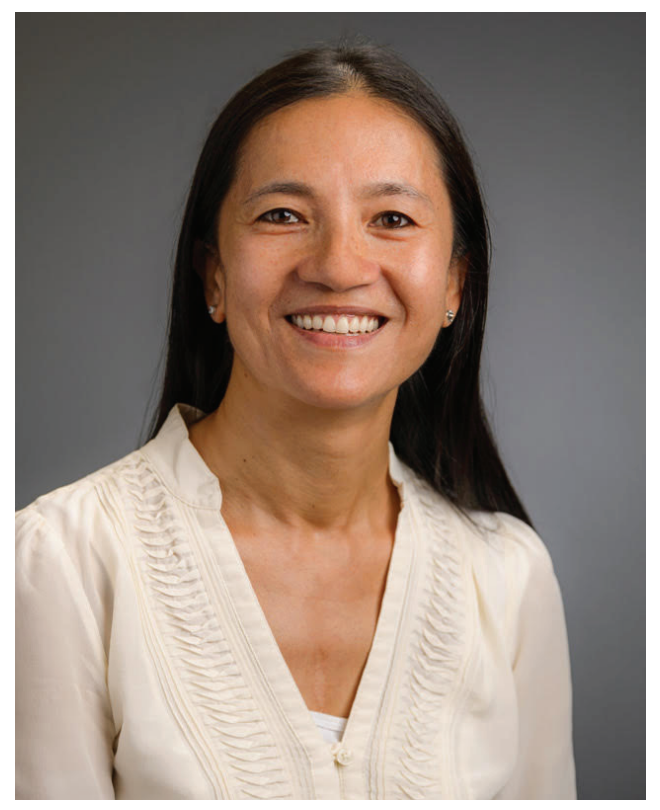

\section{Sobre a poeta}

Tsering Wangmo Dhompa, nascida em 1969, é uma poeta tibetana, exilada nos EUA. Educada em comunidades tibetanas na Índia e no Nepal, graduou-se em Nova Delhi e seguiu os estudos de Mestrado e Doutorado nos EUA. Fluente em diversas línguas e dialetos, incluindo tibetano, hindi e nepali, Dhompa escreve em inglês. Seu primeiro livro de poems Rules of the House foi finalista do Asian American Literary Awards em 2003. Também publicou outros livros de poesia, como My Rice Tastes Like the Lake e In the Absent Everyday, além do livro de memórias A Home in Tibet. 


\section{Os poemas e as traduções}

\section{Bardo}

A hundred and one butter lamps are offered to my uncle who is no more.

Distraction proves fatal in death. A curtain of butter imprints in air.

After the burning of bones, ashes are sent on pilgrimage. You are dead, go into life, we pray. My uncle was a man given to giggles in solemn moments.

Memory springs like crocuses in bloom. Self-conscious and precise.

Without blurring the cornea, details are resuscitated. Dried yak meat between teeth. Semblance of what is.

Do not be distracted, Uncle who is no more.

He does not see his reflection in the river. The arching of speech over "s" as he is becoming.

Curvature of spine as it cracked on a misty morning. A shadow evades the wall.

You are no more, Uncle who is no more.

Every seven days he must relive his moment of expiration. The living pray frequently amid burning juniper.

Communication efforts require the right initiative.

Somewhere along the line matters of motion and rest are resolved.

Crows pick the last offerings. You are someone else, uncle no more. 


\section{Bardo}

Cento e uma lamparinas de manteiga são oferecidas ao meu tio que não é mais.

A distração se revela fatal na morte. Uma cortina de manteiga é impressa no ar.

Após a queima dos ossos, as cinzas são enviadas em peregrinação. Você está morto, entra na vida, nós oramos. Meu tio era um homem dado a risadas em momentos solenes.

A memória brota como açafrões em flor. Autoconsciente e precisa.

Sem desfocar a córnea, detalhes são ressuscitados. Carne seca de iaque entre os dentes. Semelhança do que é.

Não se distraia, Tio que não é mais.

Ele não vê seu reflexo no rio. A inflexão do discurso em "s" à medida que ele está se tornando.

A curvatura da espinha ao estalar numa manhã enevoada. Uma sombra evade da parede.

Você não é mais, Tio que não é mais.

A cada sete dias ele deve reviver seu momento de expiração.

Amiúde os vivos oram no meio do zimbro que queima.

Os esforços de comunicação exigem a iniciativa correta.

Nalgum lugar ao longo da linha questões de ação e repouso são resolvidas.

Corvos escolhem as últimas oferendas. Você é outra pessoa, tio não mais. 


\section{As remembered}

I am only beginning to understand how seasons affect me.

Winter. Snow beating street people into obedience. How mothers held back from stepping out in discreetly ornamented shoes and thin nylon stocks.

This is the way I count years: the winters we had fire and the summers we erased because we were in another place.

I am told I was five in 1971 even though my birth certificate states I was born in 1969. The elders count on their fingers. They have done it for a long time.

It was winter but not the kind of winter they were born into. They were wearing hand knitted woolen sweaters. I was wearing a jacket that children born to refugees wear.

When I am with them, I cannot say I remember. I say, as I am told I remember.

It is not the accuracy of the story that concerns us.

But who gets to tell it. 


\section{Como se lembrado}

Estou só começando a entender como as estações me afetam.

Inverno. A neve forçando pessoas da rua à obediência. Como as mães

evitam sair com sapatos discretamente ornamentados e

finas meias de nylon.

É assim que conto os anos: os invernos em que tivemos fogo e os

verões que apagamos porque estávamos em outro lugar.

Disseram que eu tinha cinco anos em 1971 embora minha certidão afirme que nasci em 1969. Os idosos contam com os dedos. Têm feito assim por muito tempo.

Era inverno, mas não o tipo de inverno em que eles nasceram.

Usavam blusas de lã tricotadas à mão. Eu estava vestindo

um casaco que as crianças, filhos de refugiados, usavam.

Se estou com eles, não posso dizer que me lembro. Digo, como me foi dito me lembro.

Não é a precisão da história que nos interessa.

Mas quem consegue contá-la. 


\section{Surrender}

Between the three of us we had a garden of camellias.

The whites were planted in the middle. By the time

we changed our minds, the plants had taken root

and we took it as another lesson. The doctor

often found something wrong in one of us,

we assumed we'd grow feeble before old.

Raindrops left puddles on our clothes laid out, flattening the grass into our shapes. They would dry

but, again, there was nothing we took for granted.

If the sun came out, if thieves climbed our gates,

if naked spirits tucked damp shirts into their porous

ribs. On our side of the town, we referred to fluctuations

in our collective karma for predictions for weather

and for genes. We had many ways to introduce ourselves

but we said nothing. Said - where are you going?

And, have you eaten today? 


\section{Rendição}

Entre nós três tínhamos um jardim de camélias.

As brancas foram plantados no meio. Quando havíamos

mudado de ideia, as plantas tinham criado raízes

e tomamos isso como mais uma lição. $\mathrm{O}$ médico

com frequência encontrou algo errado em um de nós, presumimos que ficaríamos fracos antes de velhos.

Gotas de chuva deixaram poças em nossas roupas estentidas, achatando a grama com nossas formas. Eles secariam mas, de novo, não havia nada que déssemos por certo. Se o sol surgisse, se ladrões escalassem nossos portões, se espíritos nus enfiassem camisas úmidas em suas porosas costelas. Do nosso lado da cidade, nos referimos a flutuações em nosso carma coletivo para previsões meteorológicas e para genes. Tínhamos muitas maneiras de nos apresentar mas não dissemos nada. Disse - onde você está indo? e, você já comeu hoje? 


\section{(untitled poem)}

Adhering to mindfulness we say nothing.

Mother ate meat. Mother watched spiders

encamp in her domain. Nothing is not what

it seems. We take the animal we are to eat

seriously. After all, a death is involved.

The seven days of our week parted from each

other like warring cousins. In the family tree, the names of women are missing. In the family tree the low branches served well as clothesline and weapon. Once a week we question whether our country will be free. We are not warriors. We know a working bowel is proof of a healthy life. We know people who do not speak our dialect are sitting at a table. With pen and paper they will map our future. 


\section{(sem título)}

Seguindo a atenção plena não dizemos nada.

A mãe comeu carne. A mãe assistiu a aranhas acamparem no território dela. Nada não é o que parece. Levamos a sério o animal que vamos comer. Afinal, isso envolve uma morte.

Os sete dias da nossa semana se separaram uns dos outros como primos em guerra. $\mathrm{Na}$ árvore genealógica, os nomes das mulheres não constam. $\mathrm{Na}$ árvore genealógica os galhos baixos serviram bem como varal e arma. Uma vez por semana questionamos se nosso país será livre. Não somos guerreiros. Sabemos que um intestino funcionando é prova de uma vida saudável. Sabemos que pessoas que não falam nosso dialeto estão sentadas em uma mesa. Com caneta e papel elas mapearão nosso futuro.

Luci Collin, poeta, ficcionista e tradutora curitibana, já traduziu Gertrude Stein, E E Cummings, Gary Synder, Jerome Rothenberg, Vachel Lindsay entre muitos outros. Realizou dois estágios de pós-doutoramento na USP sobre tradução de poesia. É professora de Literaturas de Língua Inglesa na UFPR. 